\title{
Protective effect and mechanism of IL-10 on renal ischemia-reperfusion injury
}

\author{
Kenji Sakai ${ }^{1}$ Yuji Nozaki ${ }^{1}$ Yoshinori Murao ${ }^{2} \cdot$ Tomohiro Yano $^{3} \cdot$ Jinhai Ri $^{1} \cdot$ Kaoru Niki $^{1} \cdot$ Koji Kinoshita $^{1}$. \\ Masanori Funauchi ${ }^{1} \cdot$ Itaru Matsumura $^{1}$
}

Received: 22 July 2018 / Revised: 3 October 2018 / Accepted: 29 October 2018 / Published online: 30 January 2019

(c) United States \& Canadian Academy of Pathology 2019

\begin{abstract}
Interleukin (IL)-10, a cytokine with anti-inflammatory effects, is produced by blood cells and cells of various organs. Ischemia-reperfusion injury (IRI) is a systemic inflammatory disease caused by a systemic circulation of pro-inflammatory cytokines and chemokines produced from blood cells or organs damaged by ischemia. Apoptosis, a key event after IRI, is correlated with the degree of injury. Here we investigated the effects and mechanism of IL-10 in renal IRI. Compared to wild-type (WT) mice with a renal IRI, IL-10 knockout (IL-10 KO) mice with IRI demonstrated decreased renal function as represented by blood urea nitrogen and serum creatinine, upregulated early acute kidney injury (AKI) biomarkers such as kidney injury molecule-1 (Kim-1), increased mRNA expression of the pro-inflammatory cytokines IL-1 $\beta$, IL-6, and IL-18 and a chemokine (regulated on activation, normal T cell expressed and secreted; RANTES), and increased expression of the pro-apoptosis factors Bax and cleaved caspase-3. When tubular epithelial cells (TECs) from IL-10 KO mice were put in a hypoxic state and added with recombinant IL-10, their expression of Bax decreased. Our findings demonstrated that IL-10 suppressed the production of pro-inflammatory cytokines, renal dysfunction, and the expression of pro-apoptosis factors after IRI.
\end{abstract}

\section{Introduction}

Ischemia-reperfusion injury (IRI) in the kidney is used as a model of acute kidney injury (AKI), and several studies have described related factors such as systemic inflammation induced by inflammatory mediators and mechanisms of cell death (such as apoptosis) [1-4]. Renal IRI is also involved in renal injury after renal transplantation [1], and various cytokines and chemokines have been investigated with the goal of suppressing these disorders [5-7]. IRIs have also been reported in the liver and brain $[8,9]$.

Interleukin (IL)-10, produced by various cell types including regulatory $\mathrm{T}$ cells, is an anti-inflammatory

Kenji Sakai

kenji.s-101@hotmail.co.jp

1 Department of Hematology and Rheumatology, Kindai University School of Medicine, Osaka-Sayama, Osaka 589-8511, Japan

2 Medical Emergency Center, Kindai University School of Medicine, Osaka-Sayama, Osaka 589-8511, Japan

3 Kijima Hospital, Osaka, Osaka 597-0044, Japan cytokine [10]. IL-10 has been shown to inhibit the production of pro-inflammatory cytokines such as IL-1, tumor necrosis factor-alpha (TNF- $\alpha$ ), IL-6, and IL-18 [11-14]. IL10 is produced not only by blood cells but also by renal tissue, mostly in the epithelial cells of distal nephron segments [15]. IL-10 has also been shown to effectively suppress the progression of acute and chronic renal damage [16-20]. For example, in a murine model of chronic renal injury based on unilateral ureteral obstruction, IL-10 inhibited the reactive apoptosis caused by inflammation and downregulated apoptosis [21]. IL-10 may thus improve IRI by its inhibitory anti-inflammatory and anti-apoptotic effects.

We conducted the present study to determine whether IL10 is involved in pro-inflammatory cytokine dynamics and how it is involved in the induction of apoptosis. We used IL-10 knockout (KO) mice and compared the production of pro-inflammatory cytokines, renal dysfunction, and the expression of pro-apoptosis factors in a renal IRI of IL-10 KO and wild-type (WT) mice. We also evaluated the role of IL-10 by adding IL-10 to tubular epithelial cells (TECs) from IL-10 KO mice that were placed in a hypoxic state. 
Table 1 Primer sequences for the analysis of mRNA expression

\begin{tabular}{lll}
\hline & Forward primer $\left(5^{\prime}-3^{\prime}\right)$ & Reverse primer $\left(5^{\prime}-3^{\prime}\right)$ \\
\hline 18rRNA & GTAACCCGTTGAACCCCATTC & GCCTCACTAAACCATCCAATCG \\
IL-1 $\beta$ & TGTAATGAAAGACGGCACACC & TCTTCTTTGGGTATTGCTTGG \\
IL-10 & GGTTGCCAAGCCTTATCGGA & ACCTGCTCCACTGCCTTGCT \\
TNF- $\alpha$ & CGATCACCCCGAAGTTCAGTA & GGTGCCTATGTCTCAGCCTCTT \\
RANTES & ACACCACTCCCTGCTGCTTT & GACTGCAAGATTGGAGCACTTG
\end{tabular}

$I L$ interleukin, $I N F$ interferon, $T N F$ tumor necrosis factor, RANTES regulated on activation, normal $\mathrm{T}$ cell expressed and secreted

\section{Materials and methods}

\section{Animals}

Male B6.129P2-Il10 ${ }^{\mathrm{tm} 1 \mathrm{Cgn}} / \mathrm{J}$ (IL-10 KO) mice that were 8-10 weeks of age and weighed 22-26 g were provided by Prof. Y. Murao (Kindai University Faculty of Medicine, Osaka, Japan). Male C57BL/6 (WT) mice that were 8-10 weeks of age and weighed 22-26 g were purchased from the Shizuoka Laboratory Animal Center (Shizuoka, Japan). All animals were housed $\geq 3$ days in a specific pathogen-free animal facility under controlled light conditions and maintained under standard animal care conditions in accord with the criteria of the Kindai University Faculty of Medicine. The animal protocols were approved by the Kindai University Animal Care Committee and were performed in accord with the Kindai University Animal Care Guidelines.

\section{Ischemia protocol}

Each mouse was anesthetized with pentobarbital $(35 \mathrm{mg} / \mathrm{kg}$, intraperitoneal). After a midline incision was made, blood vessels of the bilateral renal pedicles were exposed and clamped for $30 \mathrm{~min}$ by Schwartz temporary clips (RS-5459; Roboz Surgical Instrument, Gaithersburg). Within a few seconds of the application of the clips, the color of the kidneys changed from red to dark purple due to ischemia. During the surgery, the body temperature of the mouse was maintained at $37^{\circ} \mathrm{C}$ with a homeothermic table.

After $30 \mathrm{~min}$, the clips were released from each vessel to start the reperfusion. After warm saline $(1 \mathrm{~mL})$ was placed in the abdomen cavity, the abdomen was closed. After the mouse recovered from the anesthesia, it was returned to its cage with free access to food and water.

Mice of each group (WT and IL-10 KO) were killed at 5 $(n=5), 24(n=6), 48(n=6)$, and $120 \mathrm{~h}(n=5)$ after the reperfusion. Kidney and spleen tissues were taken. Blood was collected from the dorsal aorta in heparinized tubes for the measurement of blood urea nitrogen (BUN), serum creatinine (sCr), aspartate transaminase (AST), alanine transaminase (ALT), amylase (AMY), IL-6, IL-10, IL-18, and TNF- $\alpha$.
Table 2 Gene database number for analysis of mRNA expression

\begin{tabular}{ll}
\hline & Gene database no. \\
\hline 18rRNA & NM_026744.3 \\
IL-6 & Mm00446190 \\
IL-18 & NM_008360.1 \\
Kim-1 & NM_134248.1 \\
\hline
\end{tabular}

IL interleukin, Kim-1 kidney injury molecule-1

\section{Histological analysis}

Tubular injury was assessed in periodic acid-Schiff-stained (PAS-stained) sections using a semiquantitative scale grading the percentage of cortical tubules in which epithelial necrosis, loss of the brush border, cast formation, and tubular dilation were present. These findings were applied to a five-point scale (0: normal kidney, 1: 1-25\%, 2: 26-50\%, 3: 51-75\%, 4:> 75\% tubular necrosis).

$\mathrm{CD}^{+}{ }^{+}$and $\mathrm{CD}^{+} \mathrm{T}$ cells, macrophages, and neutrophils were identified by the immunoperoxidase staining of periodate-lysine-paraformaldehyde (PLP)-fixed frozen 6mm-thick kidney sections, as described [22]. The numbers of $\mathrm{CD}^{+}$and $\mathrm{CD}^{+} \mathrm{T}$ cells, macrophages, and neutrophils were assessed in 10 fields/slide at a magnification of $\times 400$, and the results are expressed as cells per high-power field. The primary monoclonal antibodies used were rat monoclonal antibody GK1.5 for CD4 ${ }^{+}$T cells (Pharmingen, San Diego, CA), 53-6.7 for $\mathrm{CD}^{+}{ }^{\mathrm{T}}$ cells (Pharmingen), $\mathrm{CD}^{+}$ for macrophages (Serotec, Oxford, U.K.), and RB6-8C5 for neutrophils (anti-Gr-1; Pharmingen).

The presence of kidney injury molecule-1 (Kim-1) in tubular cells was examined by the immunoperoxidase staining of PLP-fixed frozen 6- $\mu$ m-thick kidney sections, as described [23]. The numbers of Kim-1-positive cells in each section were calculated by counting the number of positively stained tubular cells in 10 fields/slide at a magnification of $\times 400$. The primary monoclonal antibodies used were rat monoclonal antibody T-cell immunoglobulin and mucin domain-1 (TIM1) for Kim-1 (R\&D Systems, Minneapolis, MN).

Cleaved caspase-3 was identified in 4- $\mu$ m-thick, formalin-fixed kidney sections using rabbit antibody 
A Serum IL-10

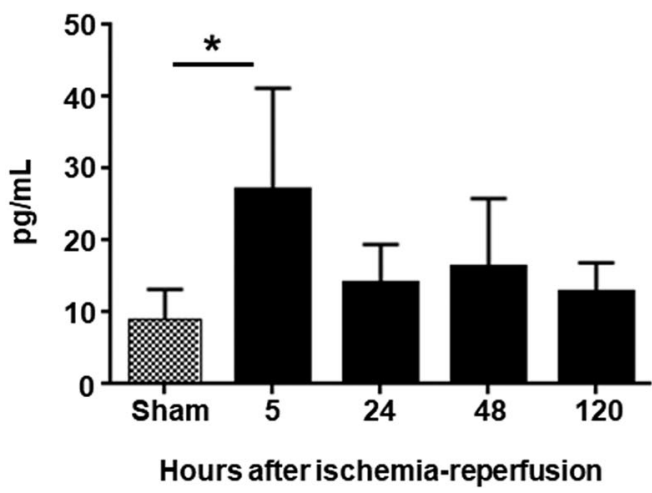

Fig. 1 IL-10 increased following IRI. a Ischemia-induced upregulation of IL-10 levels in serum from C57BL/6 mice revealed by ELISA from 5 to $120 \mathrm{~h}$ after renal IRI compared to the sham-operated controls. b Upregulation of IL-10 mRNA expression in the kidney compared to the sham-operated controls. mRNA expression were measured by realtime PCR. The expression levels were normalized to the expression of

B Renal IL-10 mRNA expression

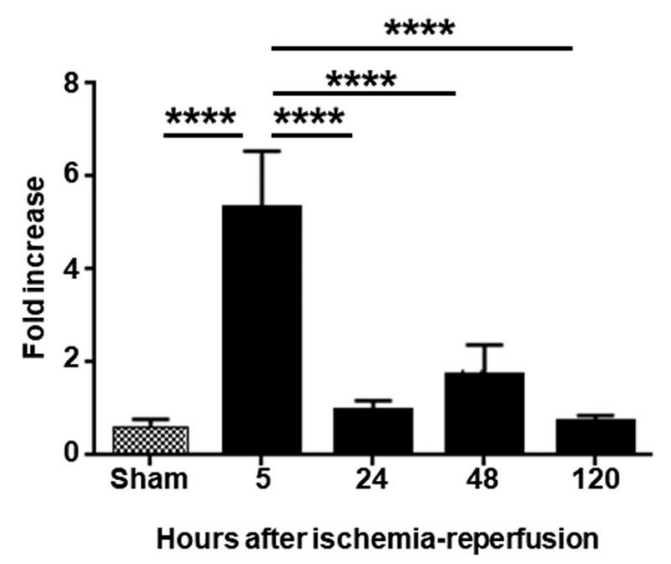

$18 \mathrm{~S}$ rRNA. The data are mean fold-increase \pm SEM. Different treatments were compared by a one-way ANOVA followed by Dunnett's test for individual comparisons between group means. $* p<0.05$, $* * * * p<0.0001, \mathrm{C} 57 \mathrm{BL} / 6$ mice at $5 \mathrm{~h}$ after IRI $(n=6)$ vs. the shamoperated control mice $(n=5)$ and C57BL/6 mice at 24,48 , and $120 \mathrm{~h}$ after IRI ( $n=6, n=6$, and $n=5)$

A

Blood urea nitrogen

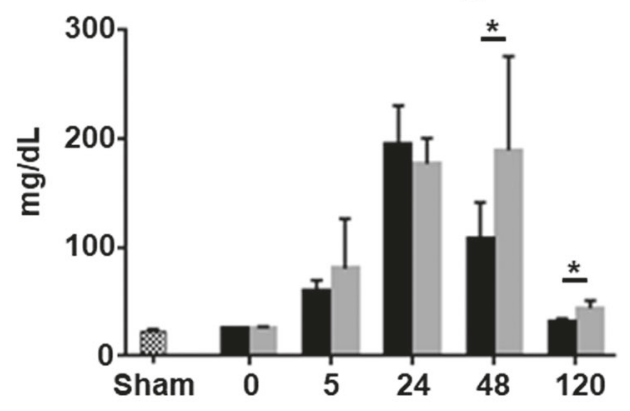

Hours after ischemia-reperfusion

C Sham

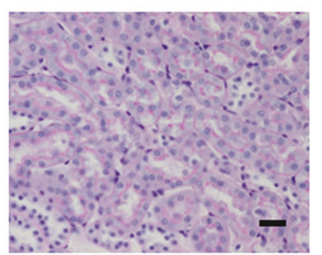

$\times 400$

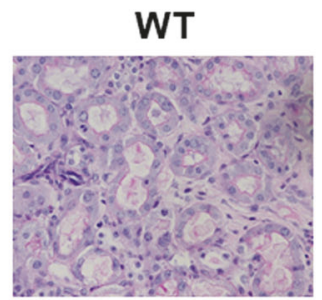

$48 \mathrm{~h}$

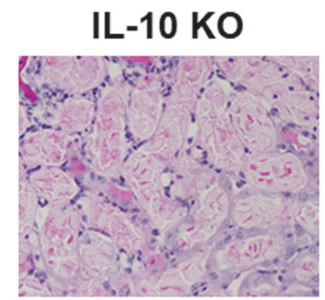

$48 \mathrm{~h}$
B

\section{Serum creatinine}

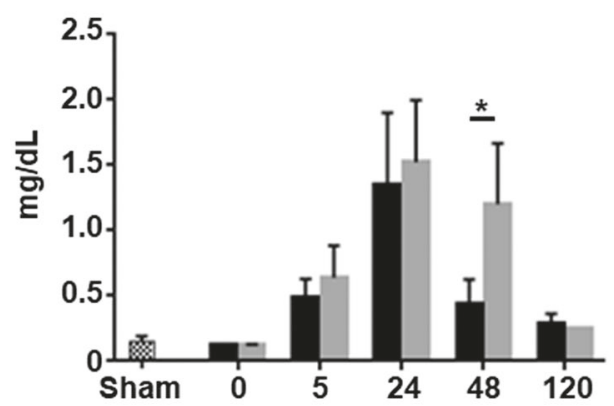

Hours after ischemia-reperfusion
Fig. 2 IL-10 knockout worsened the ischemic AKI. Renal pedicles of IL-10 KO mice and WT littermates were clamped for $30 \mathrm{~min}$. Blood and kidney tissues samples were collected at $5(n=6), 24(n=6), 48$ $(n=6)$, and $120 \mathrm{~h}(n=5)$ after renal IRI. ' $0 \mathrm{~h}$ ' indicates samples from mice that did not undergo the operation. a, b BUN and $\mathrm{sCr}$ were measured as indications of kidney function in mice exposed to IRI. c

recognizing the cleaved form of caspase-3 (Cell Signaling Technology, Beverly, MA), as described [23, 24]. The numbers of cleaved caspase-3-positive cells in each section

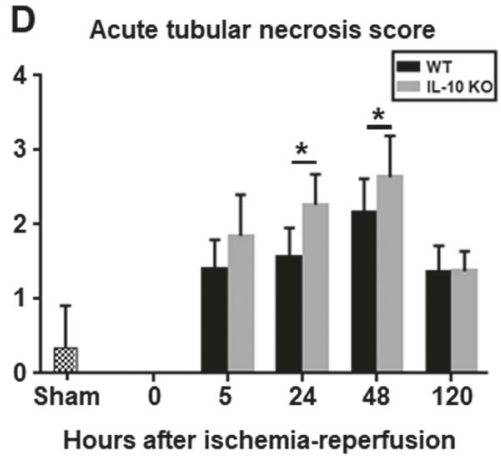

Representative morphology (by PAS staining) of kidney cortex from WT and IL-10 KO mice at $48 \mathrm{~h}$ and sham-operated mice. d ATN (acute tubular necrosis) score after IRI: Tissue damage was scored in the cortex. The data are mean \pm SEM. $* p<0.05$, WT vs. IL-10 KO mice at 24 and $48 \mathrm{~h}$. Original magnification, $\times 400$

were calculated by counting the number of positively stained tubular cells in 10 fields/slide at a magnification of $\times 400$. 
All tubules in the outer medulla were assessed for each mouse. Large blood vessels and glomeruli were excluded from the analysis. The individual who scored the slides was blinded to the treatment and the mouse strains.

\section{Real-time polymerase chain reaction (PCR) analysis}

We measured the intrarenal mRNA expression of TNF- $\alpha$, IL-1 $\beta$, RANTES (regulated on activation, normal $\mathrm{T}$ cell expressed and secreted), and 18S rRNA with the use of Sybr Green I dye (Applied Biosystems, Foster City, CA) and those of IL-6, IL-18, Kim-1, and 18S rRNA with the use of a TaqMan ${ }^{\mathrm{TM}}$ gene expression assay (Applied Biosystems) as described [25]. The sequences of primers and gene database number are listed in Tables 1 and 2. We used the comparative $\mathrm{Ct}(\Delta \Delta \mathrm{Ct})$ method to calculate the relative amounts of mRNAs. 18S rRNA was used as an endogenous control for normalization. The results are expressed as fold differences relative to the values of mice that did not undergo the ischemic surgery.

\section{Serum IL-6, IL-10, and TNF-a ELISAs}

Serum IL-6, IL-10, and TNF- $\alpha$ levels were determined by an enzyme-linked immunosorbent assay (ELISA) kit for each cytokine (BD Biosciences, San Diego, CA). The polystyrene microplates were coated with the binding

Table 3 Effects of IL-10 on the multiple organs after renal IRI

\begin{tabular}{llll}
\hline & Sham & WT & IL-10 KO \\
\hline Serum AST (IU/L) & $137.5 \pm 12.5$ & $201.3 \pm 15.7$ & $226.7 \pm 31.6$ \\
Serum ALT (IU/L) & $30.0 \pm 0.2$ & $36.2 \pm 11.4$ & $76.6 \pm 19.2$ \\
Serum AMY (U/L) & $760.0 \pm 45.0$ & $710.0 \pm 45.6$ & $1773.0 \pm 569.4^{*}$
\end{tabular}

Serum aspartate transaminase (AST), alanine transaminase (ALT), and amylase (AMY) were measured at $48 \mathrm{~h}$ after renal IRI in WT $(n=5)$ and IL-10 KO mice $(n=5)$. The data are mean fold-increase \pm SEM $* p<0.05$, WT vs. IL-10 KO antibody solution overnight. The microplate wells were washed four times with phosphate-buffered saline (PBS)/ Tween (0.05\% Tween-20 in PBS) and blocked with $200 \mu \mathrm{L}$ blocking buffer (1\% bovine serum albumin [BSA] in PBS) for $1 \mathrm{~h}$. Samples were incubated for $3 \mathrm{~h}$ at room temperature. The detection antibody was added and incubated for 1 $\mathrm{h}$ at room temperature, followed by the addition of $100 \mu \mathrm{L}$ of streptavidin-horseradish peroxidase conjugate and further incubation for $30 \mathrm{~min}$. The wells were incubated with 100 $\mu \mathrm{L}$ of stabilized chromogen (Invitrogen, Carlsbad, CA) for $30 \mathrm{~min}$ in the dark. Then, $100 \mu \mathrm{L}$ of stop solution $\left(2 \mathrm{NH}_{2} \mathrm{SO}_{4}\right)$ was added and the $\mathrm{OD}_{450}$ was measured using the ELISA microplate reader.

Serum IL-18 was measured by ELISA. The antibodies were rat anti-mouse IL-18 monoclonal antibody (MBL, Nagoya, Japan), biotinylated rat anti-mouse IL-18 (MBL), and streptavidin-HRP (Chemicon International, Billerica, MA). The plates were developed using tetramethylbenzidine substrate, and the $\mathrm{OD}_{450}$ was measured using the ELISA microplate reader. Serum Kim-1 levels were also measured by ELISA as described [25]. The antibodies were rat anti-mouse TIM-1 monoclonal antibody (R\&D Systems), biotinylated goat anti-mouse TIM-1 (R\&D Systems), and streptavidin-HRP (Chemicon International). The plates were developed using tetramethylbenzidine substrate, and the $\mathrm{OD}_{450}$ was measured using the ELISA microplate reader.

\section{Western blotting}

Proteins were extracted by homogenization of the whole kidneys at 5, 24, 48, and $120 \mathrm{~h}$ post-IRI and TECs with the use of T-PER ${ }^{\mathrm{TM}}$ Tissue Protein Extraction Reagent (Pierce, Rockford, IL) to determine the expression of Bax and Bcl-2 as described [26]. The monoclonal anti- $\beta$-actin antibody, Bax antibody, and Bcl-2 antibody were obtained from Cell Signaling Technology. Peroxidase-conjugated goat IgG was obtained from Santa Cruz Biotechnology (Santa Cruz, CA).

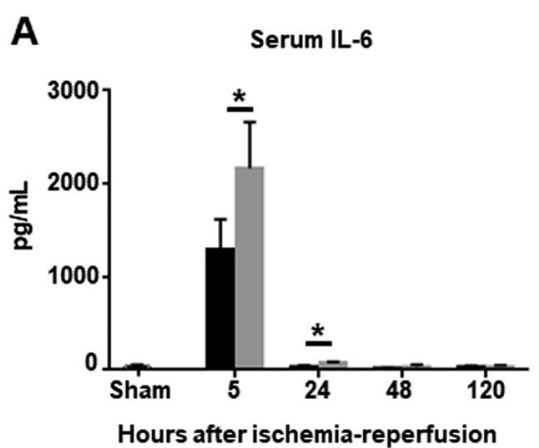

Fig. 3 Pro-inflammatory cytokine production in the blood. Blood samples from WT and IL-10 KO mice were collected at $5(n=6), 24$ $(n=6), 48(n=6)$, and $120 \mathrm{~h}(n=5)$ after renal IRI. a-c Serum IL-6,
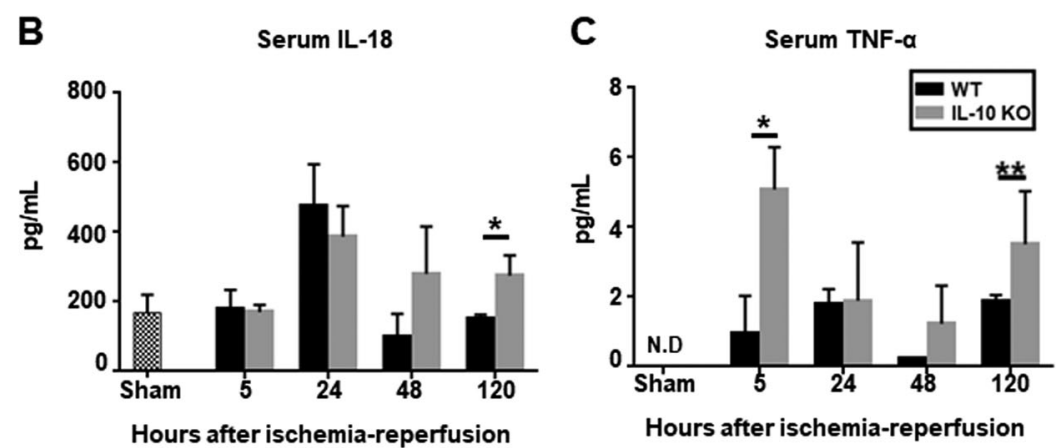

IL-18 and TNF- $\alpha$ were measured as early biomarkers in acute kidney injury (AKI). The data are mean \pm SEM. $* p<0.05$, $* * p<0.01$, WT vs. IL-10 KO mice at 5, 24, and $120 \mathrm{~h}$ 
Table 4 Effects of IL-10 on gene expression in the mouse kidney

\begin{tabular}{|c|c|c|c|c|c|c|c|c|}
\hline & \multicolumn{2}{|l|}{$5 \mathrm{~h}$} & \multicolumn{2}{|l|}{$24 \mathrm{~h}$} & \multicolumn{2}{|l|}{$48 \mathrm{~h}$} & \multicolumn{2}{|l|}{$120 \mathrm{~h}$} \\
\hline & WT & IL-10 KO & WT & IL-10 KO & WT & IL-10 KO & WT & IL-10 KO \\
\hline IL-6 & $1229.0 \pm 265.2$ & $1621.0 \pm 310.2$ & $72.3 \pm 33.0$ & $1037.0 \pm 613.5^{*}$ & $28.7 \pm 3.8$ & $38.1 \pm 11.1$ & $36.8 \pm 8.0$ & $21.2 \pm 6.3$ \\
\hline IL-18 & $1.0 \pm 0.08$ & $0.8 \pm 0.08$ & $1.7 \pm 0.2$ & $2.4 \pm 0.1 * *$ & $0.7 \pm 0.07$ & $0.6 \pm 0.05$ & $0.8 \pm 0.03$ & $1.3 \pm 0.1^{*}$ \\
\hline TNF- $\alpha$ & $2.4 \pm 0.1$ & $2.1 \pm 0.2$ & $2.2 \pm 0.2$ & $3.6 \pm 0.4 *$ & $2.4 \pm 0.1$ & $2.0 \pm 0.2$ & $2.2 \pm 0.5$ & $3.2 \pm 0.4$ \\
\hline $\mathrm{IL}-1 \beta$ & $1.8 \pm 0.4$ & $2.2 \pm 0.3$ & $0.9 \pm 0.1$ & $2.3 \pm 0.5^{*}$ & $1.0 \pm 0.07$ & $1.1 \pm 0.1$ & $0.7 \pm 0.1$ & $1.6 \pm 0.3$ \\
\hline RANTES & $0.9 \pm 0.06^{* *}$ & $0.5 \pm 0.05$ & $1.6 \pm 0.1$ & $3.6 \pm 0.9 *$ & $1.9 \pm 0.3$ & $1.0 \pm 0.4$ & $1.5 \pm 0.3$ & $4.5 \pm 0.7 *$ \\
\hline
\end{tabular}

Cytokine and chemokine gene expression was measured at $5 \mathrm{~h}(n=6), 24 \mathrm{~h}(n=6), 48 \mathrm{~h}(n=6)$, and $120 \mathrm{~h}(n=5)$ after renal IRI in WT and IL$10 \mathrm{KO}$ mice by real-time RT-PCR. In each experiment, the expression levels were normalized to the expression of $18 \mathrm{~S}$ rRNA and are expressed relative to control mice. The data are mean fold-increase \pm SEM

$* p<0.05, * * p<0.01$, WT vs. IL-10 KO mice at 5, 24, and $120 \mathrm{~h}$

\section{Administration of IL-10}

The blood vessels of the bilateral renal pedicles were clamped as described above, exposing the mice to a renal ischemic state. IL-10 KO mice received recombinant IL-10 $(0.5 \mu \mathrm{g} /$ body; Wako, Osaka, Japan $)(n=5)$ or vehicle $(n=5)$ intravenously just before the clamping. The mice were killed at $48 \mathrm{~h}$ after the reperfusion, and their kidneys were removed. Blood was collected from the dorsal aorta in heparinized tubes for the measurement of BUN and sCr.

\section{Administration of anti-IL-6 antibody}

The blood vessels of the bilateral renal pedicles were clamped as described above, expose the mice to a renal ischemic state. C57BL/6 mice received anti-mouse IL-6 antibody $(10 \mu \mathrm{g} / \mathrm{body}$; R\&D Systems) $(n=5)$ or vehicle $(n=5)$ intravenously $24 \mathrm{~h}$ before the clamping. The mice were killed at $24 \mathrm{~h}$ after the reperfusion, and their kidneys were then collected. The kidneys' Bax and Bcl-2 expression were examined by western blotting.

\section{Primary culture of mouse renal TECs}

Primary mouse TECs were generated as described [27]. Kidneys were flushed with saline to remove blood cells. The kidney cortices from an IL-10 KO mouse was cut into $\sim 1-\mathrm{mm}^{3}$ pieces, which were then digested in Hanks' balanced salt solution containing $3 \mathrm{mg} / \mathrm{mL}$ of collagenase $\mathrm{D}$ (Roche, Switzerland, Basel) at $37^{\circ} \mathrm{C}$ for $20 \mathrm{~min}$ and washed in DMEM/F12 medium (Invitrogen, Carlsbad, CA). The kidney digest was washed through a series of sieves (mesh dia. 250, 150, 75, and $40 \mu \mathrm{m}$ ).

The cortical tubular cells were spun down for $5 \mathrm{~min}$ at $4{ }^{\circ} \mathrm{C}$ $(1100 \mathrm{rpm})$ and further washed. The cell pellet was resuspended in defined $\mathrm{K} 1$ medium. The cell suspension was placed on cell culture Petri dishes and incubated for $2 \mathrm{~h}$ to facilitate the adherence of contaminating glomeruli. The nonadherent tubules were then collected and cultured on collagen-coated
Petri dishes (BD Bioscience, San Diego, CA) in K1 medium until epithelial colonies were established. The experiments were started after the cells had reached $85-90 \%$ confluence, which was usually 5-7 days after the isolation procedure.

\section{Induction of renal TEC ischemia and IL-10 (and/or IL- 6) stimulation in vitro}

TECs from IL-10 KO mice were rendered hypoxic $\left(0.1 \% \mathrm{O}^{2}\right)$ with a BIONIX hypoxic culture kit (Sugiyama-gen, Tokyo) for $3 \mathrm{~h}$ at $37^{\circ} \mathrm{C}$ in serum-free $\mathrm{K} 1$ medium. This process induced simulated ischemia by restricting the cellular exposure to oxygen. As the non-ischemic control, TECs were exposed to serum-free K1 medium alone. After the TECs were released from the hypoxic state, recombinant mature IL-10 $(10,100$, or $1000 \mathrm{pg} / \mathrm{mL}$; Wako) and/or IL-6 (2,000 pg/mL; Wako) was added to the TECs and incubated at $37^{\circ} \mathrm{C}$ at $24 \mathrm{~h}$ after medium replacement. The cells were then collected, and the cells' Bax and $\mathrm{Bcl}-2$ expression were examined by western blotting.

\section{Statistical analysis}

Results are expressed as the mean \pm SEM. The unpaired $t$ test was used for the statistical analyses, and differences were accepted as significant when the $p$-value was $<0.05$. When multiple comparisons were made, different treatments were compared by a one-way analysis of variance (ANOVA) followed by Dunnett's test for individual comparisons between group means. We analyzed the data using GraphPad Prism software (GraphPad, La Jolla, CA).

\section{Results}

\section{IL-10 expression is increased in the mouse kidney following kidney ischemia}

To determine whether kidney ischemia stimulates the upregulation of IL-10, we measured serum IL-10 levels by 


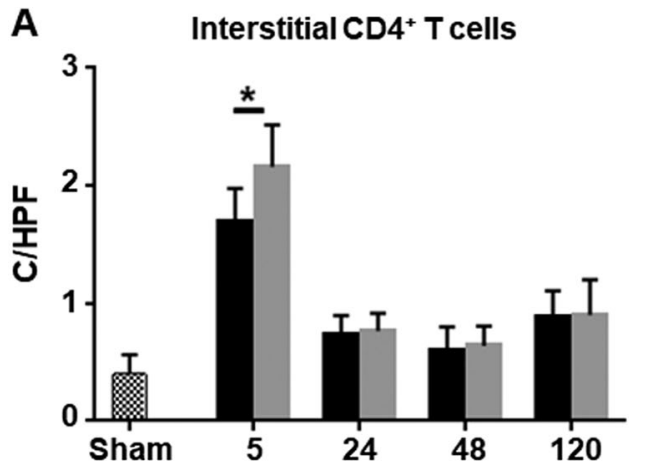

Hours after ischemia-reperfusion

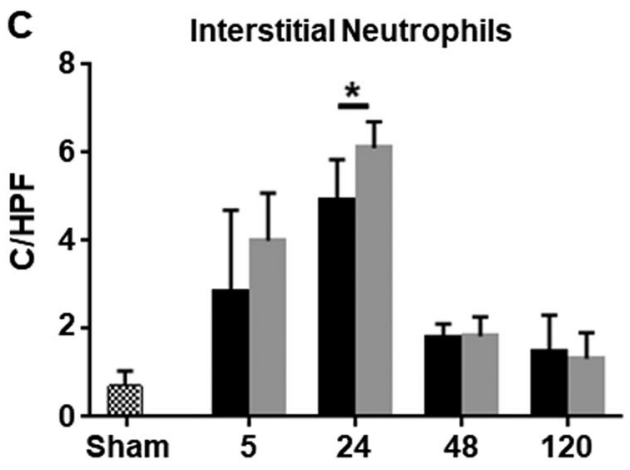

Hours after ischemia-reperfusion

Fig. 4 The infiltration of $\mathrm{CD}^{+}$and $\mathrm{CD}^{+} \mathrm{T}$ cells, macrophages, and neutrophils in renal IRI. The interstitial accumulation of leukocytes after renal ischemia-reperfusion in WT and IL-10 KO mice at 5

an ELISA and determined the mRNA expression of IL-10 in IRI mouse kidneys by real-time PCR. Normal kidney tissue expressed IL-10 at a basal level. Serum IL-10 levels were increased at $5 \mathrm{~h}$ post-ischemia (Fig. 1a). Similar findings were found regarding the mRNA IL-10 levels (Fig. 1b).

\section{IL-10 knockout worsened ischemic AKI}

Compared to the sham-operated mice, IRI caused significant increases in BUN and $\mathrm{sCr}$ at 5, 24, and $48 \mathrm{~h}$. We also compared the response of WT versus IL-10 KO kidneys to IRI caused by temporarily occluding the renal pedicle. At $48 \mathrm{~h}$ of reperfusion, both measures of renal function (i.e., BUN and $\mathrm{sCr}$ ) were significantly increased in the IL-10 KO mice compared to the WT mice (BUN: WT, $108.4 \pm 14.7$ vs. IL-10 KO, $220.8 \pm 20.4 \mathrm{mg} / \mathrm{dL}$; sCr: WT, $0.4 \pm 0.1$ vs. IL-10 KO, $1.2 \pm 0.2 \mathrm{mg} / \mathrm{dL})$. At $120 \mathrm{~h}$ after reperfusion, the $\mathrm{BUN}$ and $\mathrm{sCr}$ levels were similarly decreased and close to baseline (Fig. 2a, b).

In addition, we analyzed the histology of the kidneys by scoring tubular damage and inflammation. After IRI, we observed more injury and inflammation in the IL-10 KO ischemic kidneys (Fig. 2c). Kidney injury scores at 24 and $48 \mathrm{~h}$ after IRI were significantly more severe in the IL-10
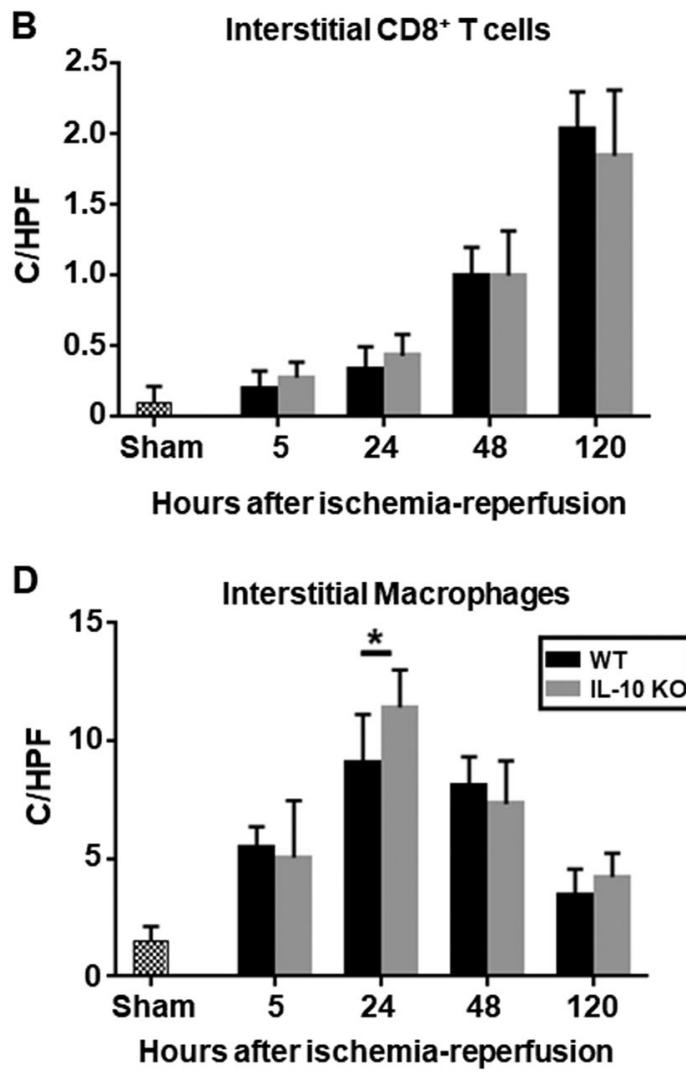

$(n=6), 24(n=6), 48(n=6)$, and $120 \mathrm{~h}(n=5)$ after renal IRI. The data are mean \pm SEM. $* p<0.05$, WT vs. IL- $10 \mathrm{KO}$ mice at 5 and $24 \mathrm{~h}$

KO kidneys compared to the WT kidneys (WT, $1.5 \pm 0.1$ vs. IL-10 KO, $2.2 \pm 0.1$ at $24 \mathrm{~h}$; WT, $2.2 \pm 0.2$ vs. IL-10 $\mathrm{KO}, 2.9 \pm 0.1$ at $48 \mathrm{~h}$ ) (Fig. $2 \mathrm{~d}$ ).

\section{Renal IRI results in distant organ disorder}

To evaluate the liver and pancreatic disorders after renal IRI and the action of IL-10 against them, we measured serum AST, ALT and AMY from WT mice and IL-10 KO mice at $48 \mathrm{~h}$ after IRI. Serum AST and ALT levels of the operated mice were increased compared to the sham-operated mice, but no significant difference in serum AST and ALT levels was observed between the WT mice and IL-10 KO mice. Serum AMY was significantly increased in the IL-10 KO mice $(1733.0 \pm 569.4 \mathrm{U} / \mathrm{L})$ compared to the WT mice $(710.0 \pm 45.6 \mathrm{U} / \mathrm{L})($ Table 3$)$.

\section{IL-10 mediates Th1 cytokine and chemokine expression in the mouse serum and kidney after IRI}

To further determine the effect of IL-10 signaling in the IRI model, we examined the expression of Th1 cytokines and chemokines. Serum IL-6 and IL-18 levels as Th1 cytokines in the IL-10 KO mice were significantly increased compared to those in the WT mice (IL-6: WT, 1294.2 \pm 144.7 
A

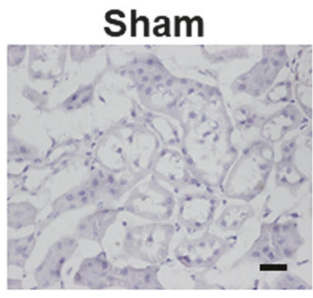

$\times 400$

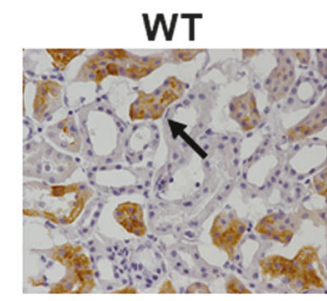

$24 \mathrm{~h}$

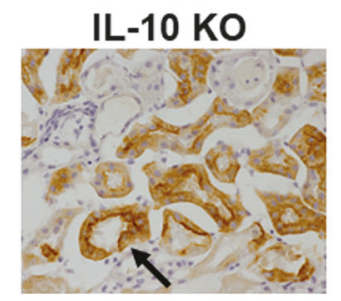

$24 \mathrm{~h}$
B

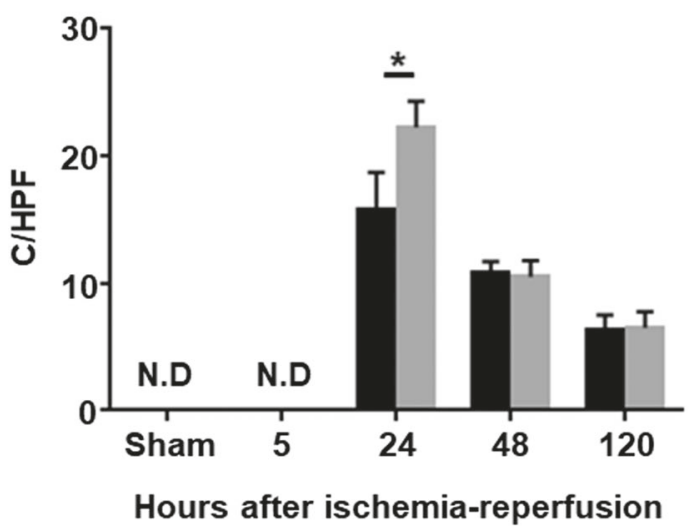

C

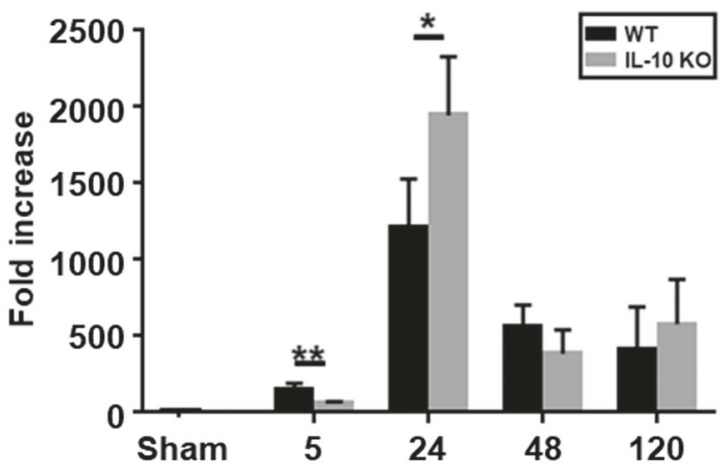

Hours after ischemia-reperfusion

Fig. 5 IL-10 mediates Kim-1 expression as an AKI marker post-IRI. Kim-1 expression in the kidneys of WT and IL-10 KO mice. a Representative photographs of the kidney at $24 \mathrm{~h}$ after renal IRI and from sham-operated mice. Arrow: A Kim-1-positive TEC. b The number of Kim-1-positive cells in ten $\times 400$ fields at $5(n=6), 24(n=6), 48(n=6)$, and $120 \mathrm{~h}(n=5)$ after renal IRI. c Expression of Kim- 1 mRNA in the kidney at 5, 24, 48 , and $120 \mathrm{~h}$ after IRI. The data are means and fold-increase \pm SEM. ${ }^{*} p<0.05$, $* * p<0.01$, WT vs. IL-10 KO mice at 5 and $24 \mathrm{~h}$. Orig. magn. $\times 400$. Scale bar, $50 \mu \mathrm{m}$

vs. IL-10 KO, 2164.4 $\pm 221.7 \mathrm{pg} / \mathrm{mL}$ at $5 \mathrm{~h}$; IL-18: WT, $150.0 \pm 5.9$ vs. IL-10 KO, $285.0 \pm 23.7 \mathrm{pg} / \mathrm{mL}$ at $120 \mathrm{~h}$ ) (Fig. 3a, b). Serum TNF- $\alpha$ levels were significantly increased in the IL-10 KO mice compared to those in the WT mice (WT, $0.9 \pm 0.5$ vs. IL-10 KO, $5.0 \pm 0.5 \mathrm{pg} / \mathrm{mL}$ at $5 \mathrm{~h}$; WT, $1.8 \pm 0.1$ vs. IL-10 KO, $3.5 \pm 0.6 \mathrm{pg} / \mathrm{mL}$ at $120 \mathrm{~h}$ ) (Fig. 3c). Serum interferon-gamma (IFN- $\gamma$ ) level was not detected in the WT or IL-10 KO mice (graph is omitted).

We also measured the expression of Th1 (IL-6 and IL-18) chemoattractant. The IL-6 mRNA expression in the IL-10 KO kidneys was increased compared to that in the WT kidneys at $24 \mathrm{~h}$ (WT, $72.3 \pm 33.0$ vs. IL-10 KO, $1037.0 \pm 613.5$ foldincrease). The IL-18 mRNA expression in the IL-10 KO kidneys was increased compared to that in the WT kidneys at $24 \mathrm{~h}$ (WT, $1.7 \pm 0.2$ vs. IL-10 KO, $2.4 \pm 0.1$ fold-increase). The intrarenal chemokine mRNA expression (RANTES; a Th1 cell chemoattractant) in the IL-10 KO mice was also increased compared to that in the WT mice at $24 \mathrm{~h}$ (WT, 1.60 \pm 0.19 vs. IL-10 KO, $3.61 \pm 0.93$ fold-increase) (Table 4).

\section{The numbers of inflammatory cells were increased in the IL-10 KO mice}

We investigated the infiltration of inflammatory cells (i.e., $\mathrm{CD}^{+}$and $\mathrm{CD}^{+} \mathrm{T}$ cells, macrophages, and neutrophils) in the renal interstitium at 5, 24, 48, and $120 \mathrm{~h}$ after IRI. The numbers of interstitial CD $4^{+} \mathrm{T}$ cells in the IL-10 KO mice at $5 \mathrm{~h}$ were significantly increased compared to those in the WT mice. The numbers of interstitial macrophages and neutrophils in the IL-10 KO mice at $24 \mathrm{~h}$ were significantly increased compared to those in the WT mice. No significant difference in the number of $\mathrm{CD}^{+} \mathrm{T}$ cells was observed between the IL-10 KO and WT mice. AT 48 and $120 \mathrm{~h}$, the numbers of these inflammatory cells were not significantly different between the two groups (Fig. 4).

\section{Renal Kim-1 expression}

Figure 5 shows the tubular Kim-1 expression after IRI. In the sham-operated mice, Kim-1 was not detected in the kidney. However, Kim-1 expression was present in tubules from the kidneys of IRI mice after $24 \mathrm{~h}$. In the IL-10 KO mice, the number of Kim-1-positive cells was increased at $24 \mathrm{~h}$ compared to the WT mice after renal IRI (WT, $15.8 \pm$ 1.5 vs. IL-10 KO, $22.3 \pm 1.0 \mathrm{c} / \mathrm{hpf}$ ) (Fig. 5a, b). At $48 \mathrm{~h}$, the number of Kim-1-positive cells was significantly decreased in both the WT and IL-10 KO mice with IRI compared to the values at $24 \mathrm{~h}$. Similarly, the Kim-1 mRNA expression in the IL-10 KO kidneys was increased compared to that in the WT kidneys at $24 \mathrm{~h}$ after IRI (WT, 
A

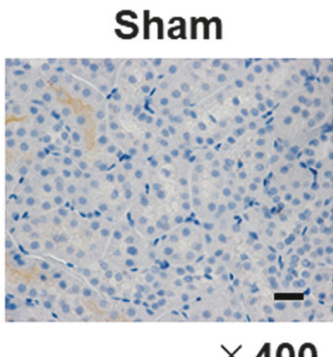

$24 \mathrm{~h}$

$48 \mathrm{~h}$

\section{B Interstitial cleaved caspace-3}

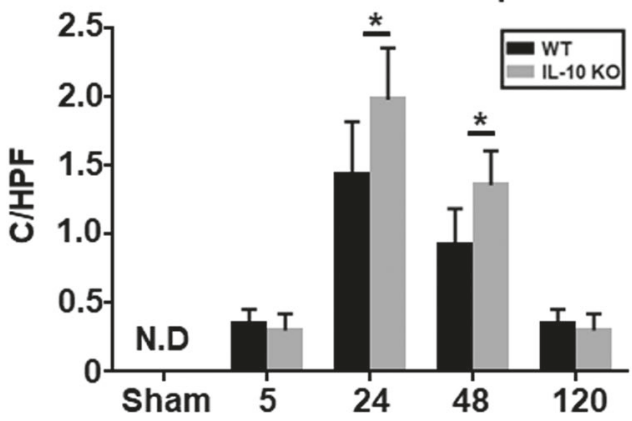

Hours after ischemia-reperfusion

Fig. 6 Tubular cleaved caspase-3 expression as an apoptosis marker post-IRI. Tubular interstitial cleaved caspase- 3 expression in the kidneys of WT and IL-10 KO mice. a Representative photographs of kidneys at 24 and $48 \mathrm{~h}$ after renal IRI, and from sham-operated mice. Arrow: An interstitial cleaved caspase-3-positive TEC. b The number

$1215.2 \pm 140.7$ vs. IL-10 KO, $1946.2 \pm 171.1$ fold-increase) (Fig. 5c).

\section{IL-10 mediates tubular apoptosis after IRI}

Apoptosis represents a key event after IRI, correlating with the degree of injury. Tubular cells expressing interstitial cleaved caspase-3, a marker of apoptosis, were not present in the sham-operated mice but were present after $24 \mathrm{~h}$ in the mice that received IRI (Fig. 6a). At $24 \mathrm{~h}$, the number of tubular cells expressing interstitial cleaved caspase-3 was significantly increased in the IL-10 KO mice compared to that in the WT mice at 24 and $48 \mathrm{~h}$ (WT, $1.4 \pm 0.5 \mathrm{vs}$. IL-10 $\mathrm{KO} ; 2.0 \pm 0.8 \mathrm{c} / \mathrm{hpf}$ at $24 \mathrm{~h}$; WT, $0.9 \pm 0.8$ vs. IL-10 KO, $1.4 \pm 0.7 \mathrm{c} / \mathrm{hpf}$ at $48 \mathrm{~h}$ ) (Fig. $6 \mathrm{~b}$ ).

We further investigated the expression of renal Bax as a marker of pro-apoptosis after IRI by immunofluorescence and western blotting analyses. In the IL-10 KO mice, the levels of Bax-positive tubules were significantly increased at $24 \mathrm{~h}$ (WT, $1.2 \pm 0.3$ vs. IL-10 KO, $1.8 \pm 0.2 \mathrm{c} / \mathrm{hpf}$ ) (Fig. 7a, b). The ratio of Bax/Bcl-2 assayed by western of tubular interstitial cleaved caspase-3-positive cells in ten $\times 400$ fields at $5(n=6), 24(n=6), 48(n=6)$, and $120 \mathrm{~h}(n=5)$ after IRI. The data are mean \pm SEM. $* p<0.05$, WT vs. IL-10 KO mice at 24 and 48 h. Orig. magn., $\times 400$. Scale bar, $50 \mu \mathrm{m}$

blotting in the IL-10 KO mice was significantly higher compared to that in the WT mice at 24 (IL-10 KO, 7.6 \pm 1.4 vs. WT, $2.7 \pm 0.6$ ) and $120 \mathrm{~h}$ (IL-10 KO, $2.2 \pm 0.1$ vs. WT, $1.7 \pm 0.2$ ) (Fig. 7c, d).

\section{IL-10 improves the ischemic AKI}

To observe whether IL-10 has a protective effect against renal dysfunction after IRI, we administered recombinant IL-10 to IL-10 KO mice. Both measures of renal function (i.e., BUN and $\mathrm{sCr}$ ) were significantly increased in the nonadministration (vehicle) group compared to the IL-10 administration group, as follows. (BUN: Vehicle, 233.2 \pm $37.1 \mathrm{mg} / \mathrm{dL}$ vs. IL-10, $120.7 \pm 18.8$. sCr: Vehicle, $1.7 \pm 0.7$ $\mathrm{mg} / \mathrm{dL}$ vs. IL-10, $0.6 \pm 0.1$ ) (Fig. 8a, b).

We analyzed the histology of the kidneys based on the acute tubular necrosis (ATN) score. After IRI, we observed more injury and inflammation in the vehicle group's kidneys (Fig. 8c). The ATN scores were significantly more severe in the vehicle group compared to the IL-10 administration group (Vehicle, $2.6 \pm 0.2$ vs. IL-10, $2.0 \pm 0.1$ ) (Fig. 8d). 
A

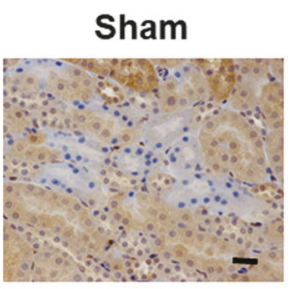

$\times 400$

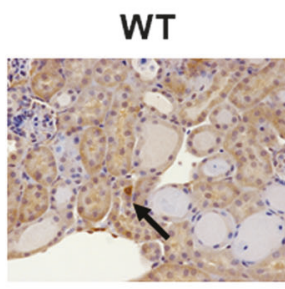

$24 \mathrm{~h}$

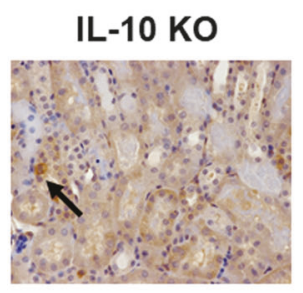

$24 \mathrm{~h}$

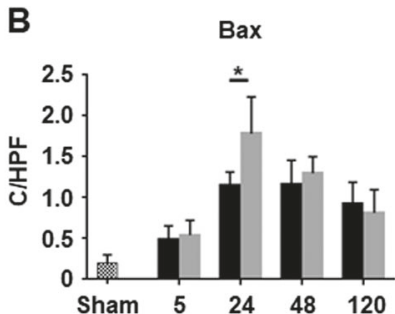

Hours after ischemia-reperfusion

C
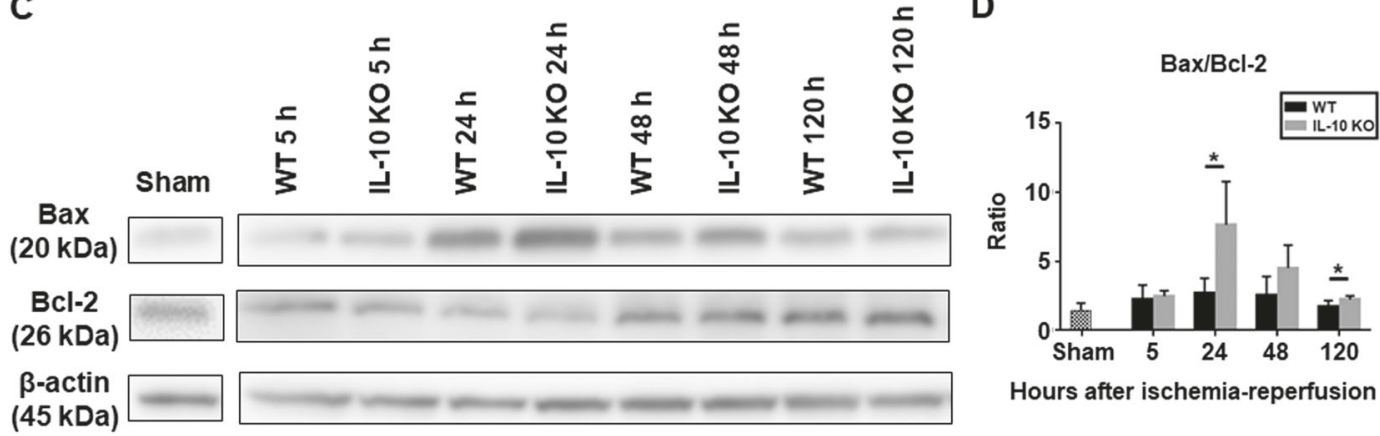

Hours after ischemia-reperfusion

Fig. 7 IL-10 mediates Bax as a pro-apoptosis marker in the apoptosis pathway after IRI. The expression of Bax in the kidneys of WT and IL$10 \mathrm{KO}$ mice. a Representative photographs of kidneys at $24 \mathrm{~h}$ after renal IRI and from sham-operated mice. Arrow: A Bax-positive TEC. b The number of Bax-positive cells in ten $\times 400$ fields at $5(n=6), 24$ $(n=6), 48(n=6)$, and $120 \mathrm{~h}(n=5)$ after IRI. c, $\mathbf{d}$ The ratio of Bax/ Bcl-2 at 5, 24, 48, and $120 \mathrm{~h}$ as assayed by western blotting. The data are mean changes \pm SEM. $* p<0.05$, WT vs. IL- $10 \mathrm{KO}$ mice at 24 and $120 \mathrm{~h}$. The pictures show a representative band. Orig. magn., $\times 400$. Scale bar, $50 \mu \mathrm{m}$
A

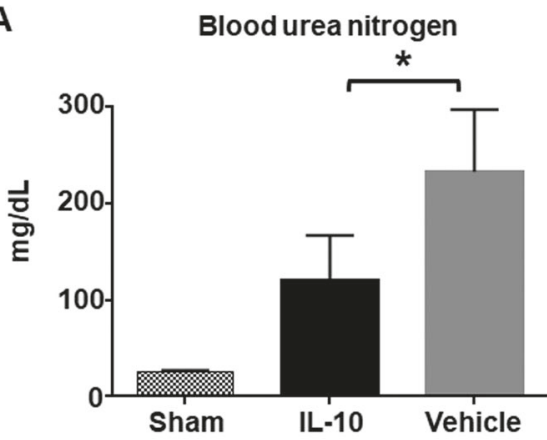

C

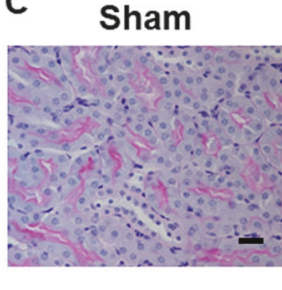

$\times 400$
B

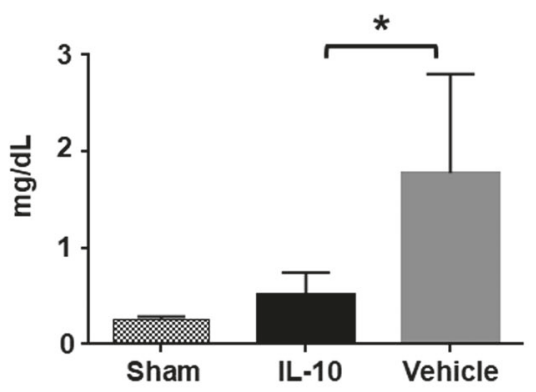

Vehicle
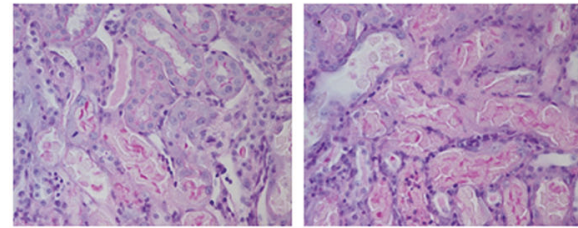

D Acute tubular necrosis score

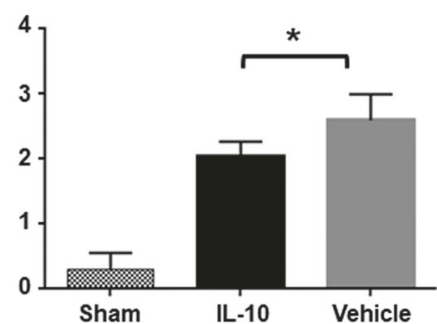

of kidney cortex from IL-10 KO mice and sham-operated mice. d ATN scores after IRI: Tissue damage was scored in the cortex. The data are mean \pm SEM. $* p<0.05$, recombinant IL-10 administration group vs. vehicle group. Orig. magn., $\times 400$ intravenously just before ischemia and killed at $48 \mathrm{~h}$ post-ischemia. a b $\mathrm{BUN}$ and $\mathrm{sCr}$ were measured as indications of kidney function in mice exposed to IRI. c Representative morphology (by PAS staining) 
A
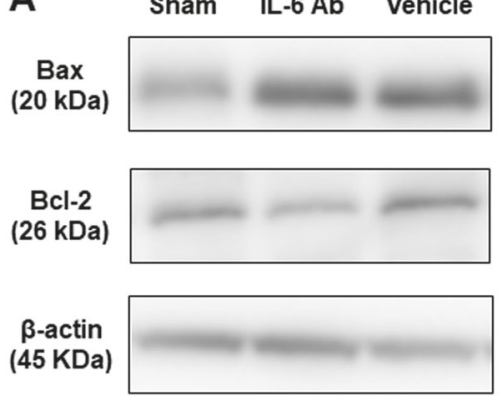

B
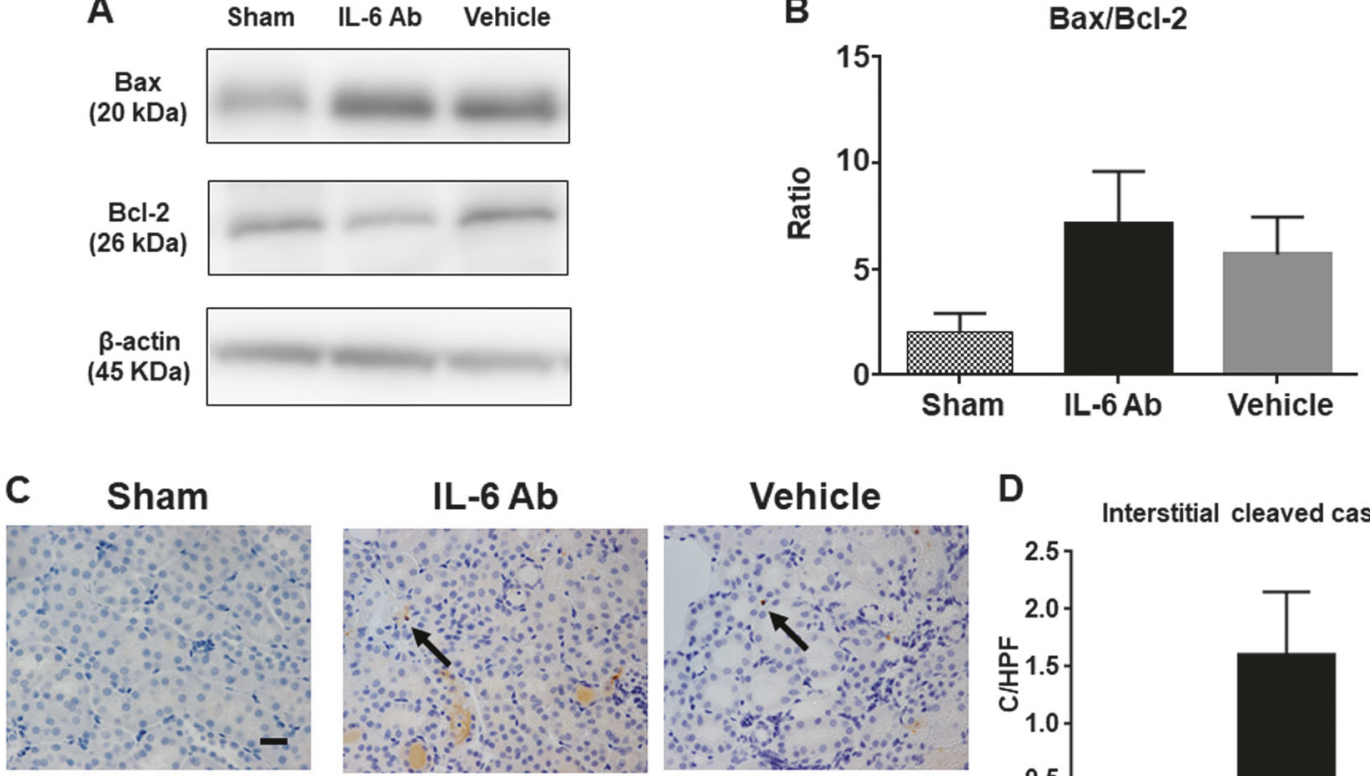

$\times 400$

Fig. 9 Effect of IL-6 on apoptosis after IRI. C57BL/6 mice received $10 \mu \mathrm{g} /$ body anti-IL-6 antibody $(n=5)$ or vehicle $(n=5)$ intravenously $24 \mathrm{~h}$ before ischemia and killed at $24 \mathrm{~h}$ post-ischemia. a, b The ratio of $\mathrm{Bax} / \mathrm{Bcl}-2$ as assayed by western blotting. The data are mean changes \pm SEM. The pictures show a representative band. c Representative

\section{IL-6 does not mediate tubular apoptosis after IRI}

To observe whether IL-6 has an effect against kidney apoptosis after IRI, we administered anti-IL-6 antibody (IL$6 \mathrm{Ab})$ to C57BL/6 mice. No significant difference in the ratio of $\mathrm{Bax} / \mathrm{Bcl}-2$ was observed between the IL-6 $\mathrm{Ab}$ administration group and vehicle group (Fig. 9a, b). We also evaluated the kidneys' apoptosis based on the expression of interstitial cleaved caspase-3. There was no significant difference between the IL-6 Ab administration and Vehicle groups in the number of tubular cells expressing interstitial cleaved caspase-3 (Fig. 9c, d). An effect of IL-6 on apoptosis in the kidneys after IRI was not demonstrated in this experiment.

\section{IL-10 mediates apoptosis in TECs}

We evaluated the ability of IL-10 and IL-6 to stimulate TECs by exposing renal TECs to recombinant IL-10 and IL6 in vitro. The ratio of $\mathrm{Bax} / \mathrm{Bcl}-2$ assayed by western blotting in the TECs added with IL-10 was significantly lower compared to those in the TECs not added (IL-10 added, $2.4 \pm 0.5$; not added, 5.9 \pm 0.8 ) (Fig. 10a, b). No significant difference in the ratio of $\mathrm{Bax} / \mathrm{Bcl}-2$ was observed between the IL-6 added and not-added groups (Fig. 10c, d). No significant difference in the ratio of $\mathrm{Bax} / \mathrm{Bcl}-2$ was observed between the IL-10 added group and IL-10 notadded group when IL-6 was added (Fig. 10e, f). The ratio of $\mathrm{Bax} / \mathrm{Bcl}-2$ in the TECs stimulated with recombinant IL-10 after oxygen blocking was dose-dependent (Fig. 11a, b).

\section{Discussion}

Our present findings demonstrated that IL-10 knockout worsened the renal function of mice and upregulated the production of pro-inflammatory cytokines (IL-6, IL-18, and TNF- $\alpha$ ) after IRI. We also observed that IL-10 suppressed the expression of the pro-apoptosis factor Bax in TECs under a hypoxic state.

As noted in the Introduction section, IRI is considered one of the systemic inflammatory diseases caused by the systemic circulation of pro-inflammatory cytokines and chemokines produced from monocytes or organs damaged by ischemia [1-4]. IL-10 was reported to inhibit the production of pro-inflammatory cytokines and chemokines and has been shown to limit inflammation-mediated organ injury in both infectious [28-32] and non-infectious $[33,34]$ causes of systemic inflammatory response syndrome. The anti-inflammatory effects of IL-10 are mediated by $\mathrm{IL}-10$ receptor $[35,36]$ and stat-SOCS signaling $[37,38]$. 
A

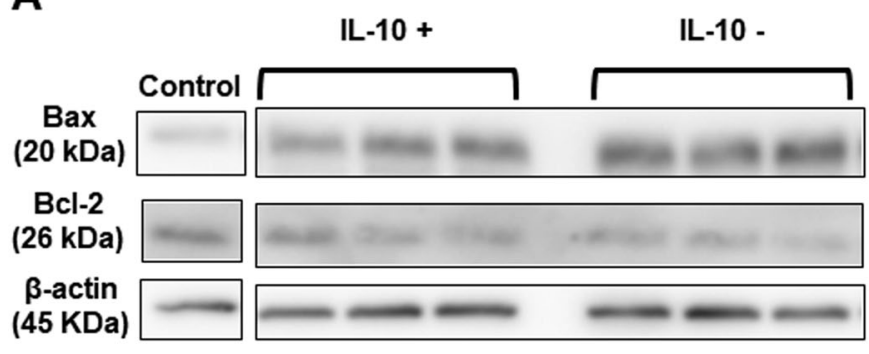

C

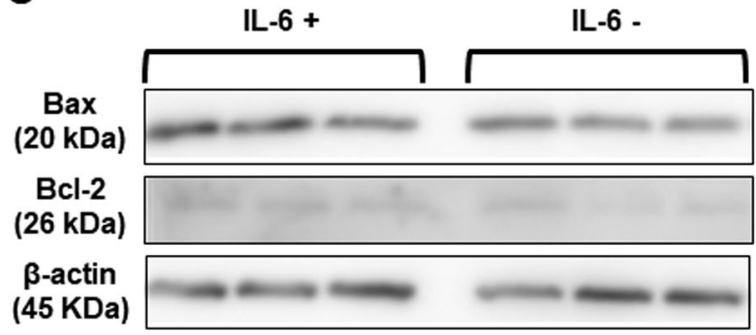

E

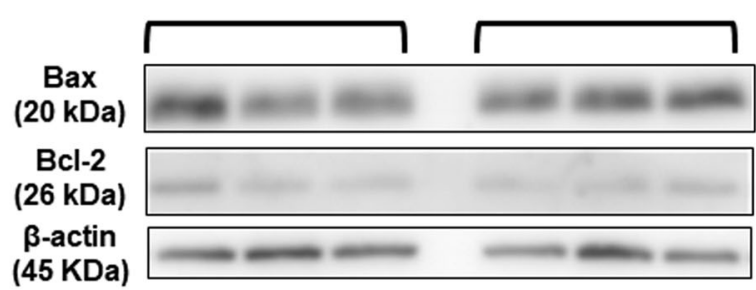

B

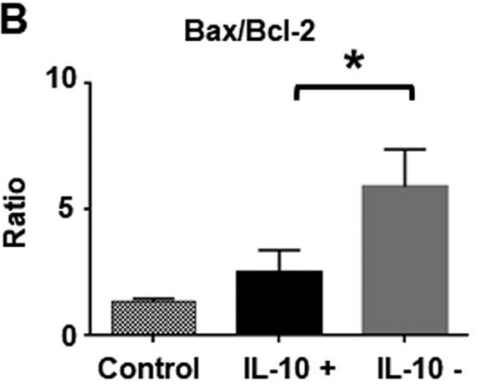

D

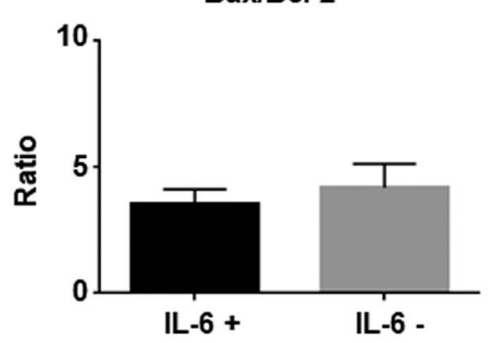

$\mathbf{F}$

$\mathrm{Bax} / \mathrm{Bcl}-2$

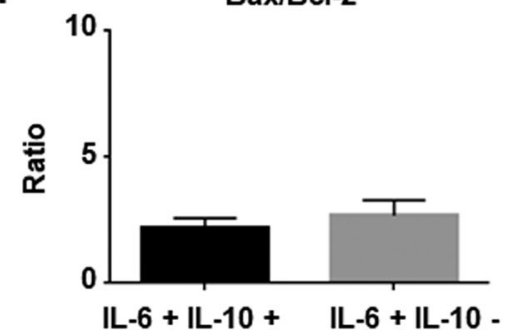

Fig. $10 \mathrm{IL}-10$ decreased the expression of Bax and Bcl-2 on TECs after incubation in a hypoxic state. TECs following IL-10 stimulation and the expression of Bax and Bcl-2 in TECs. a, b TECs of IL-10 KO mice were incubated in a hypoxic state for $3 \mathrm{~h}$. We then added recombinant IL-10 $(100 \mathrm{pg} / \mathrm{mL})$ and incubated the TECs for $24 \mathrm{~h}$. The ratio of $\mathrm{Bax} / \mathrm{Bcl}-2$ in TECs with recombinant IL-10 administration $(n=4)$ or Vehicle alone $(n=4)$. The data are mean changes \pm SEM. $* \mathrm{p}<0.05$, recombinant IL-10 administration group vs. Vehicle group. The pictures show a representative band. c, $\mathbf{d}$ TECs of IL-10 KO mice were incubated in a hypoxic state for $3 \mathrm{~h}$. The cells were then added

Wan et al. [39] reported that the IL-10 KO mice with IRI showed increased inflammatory mediators (i.e., TNF- $\alpha$ and IL-6) and histologic renal injury, and the IL-10 KO mice had less ki67-positive cells in the proximal tubules and focally in the interstitium. Deng et al. reported that IL-10 significantly decreased renal injury following renal IRI and following cisplatin administration, and they noted that IL10 inhibited ischemia and cisplatin-induced increases in TNF- $\alpha$ mRNA expression, intercellular adhesion molecule1 , and nitric oxide synthase-2. In addition, IL-10 inhibited staining for a marker of apoptosis following cisplatin administration and nitric oxide production in cultured TECs [18].

We demonstrated that IL-10 affects apoptosis in TECs. IL-10 is dependent on the concentration of IL- 6 and produced by $\mathrm{CD} 4^{+} \mathrm{T}$ cells, $\mathrm{CD} 11^{+}$cells, and B cells [40]. IL-6 with recombinant IL-6 $(2000 \mathrm{pg} / \mathrm{mL})$ and incubated for $24 \mathrm{~h}$. The ratio of Bax/Bcl-2 in TECs with recombinant IL- 6 administration $(n=4)$ or non-administration $(n=4)$. The data are mean changes \pm SEM. The pictures show a representative band. e, $\mathbf{f}$ TECs of IL-10 KO mice were incubated in a hypoxic state for $3 \mathrm{~h}$. The cells were then added with recombinant IL-6 $(2000 \mathrm{pg} / \mathrm{mL})$ and recombinant IL-10 $(100 \mathrm{pg} / \mathrm{mL})$ and incubated for $24 \mathrm{~h}$. The ratio of Bax/Bcl-2 in TECs with recombinant IL-6 and recombinant IL-10 administration $(n=4)$ or only recombinant IL- 6 administration $(n=4)$. The data are mean changes \pm SEM. The pictures show a representative band

was initially regarded as a pro-inflammatory cytokine, but subsequent studies revealed that IL-6 has diverse biological activities. It was reported that IL-6 prevented intestinal epithelium's apoptosis during prolonged inflammation [41]. However, in the present study, anti-apoptotic effects by IL-6 in TECs were not observed in vivo or in vitro. Here we examined whether the expression of Bax was affected by the addition of recombinant IL-6 plus recombinant IL-10 to TECs in a hypoxic state. There was no significant difference in the expression of Bax between the recombinant IL-10 and IL- 6 administration group and only IL- 6 administration group. In addition, the expression of interstitial cleaved caspase- 3 and Bax in the kidney were not significantly different between the IL-10 KO mice and the WT mice at 5 $\mathrm{h}$ after IRI, when the IL-6 level in serum appeared to be at its peak. On the other hand, significantly increased 
A

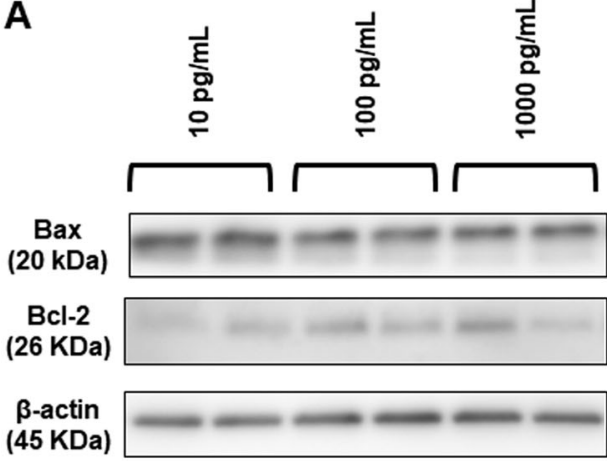

Fig. 11 Graphic representation of the TECs' response to recombinant IL-10 stimulation (10-1000 pg/mL). The expression of Bax and Bcl-2 in TECs following IL-10 stimulation. a, b The ratio of Bax/Bcl-2 in TECs added with recombinant IL-10 at $10(n=4), 100(n=4)$, or $1000 \mathrm{pg} / \mathrm{mL}(n=4)$. The data are mean changes \pm SEM. Different

expression of interstitial cleaved caspase- 3 and Bax were observed in IL-10 KO mice at $24 \mathrm{~h}$ after IRI, which is when the IL-6 in serum showed a decrease. Although serum IL-10 levels and IL-10 mRNA expression in the kidney peaked at $5 \mathrm{~h}$ after IRI, significant differences in the expression of proapoptotic factors and renal function were observed in the IL-10 KO mice at $24 \mathrm{~h}$ after IRI. It appears that when IL-6 is present at a high concentration (i.e., at the early stage of IRI), there may be interactions between IL-10 and IL- 6 that have not yet been elucidated.

In summary, we determined the effect of IL-10 in IRI. IL-10 has anti-inflammatory and anti-apoptotic effects in IRI and suppresses the expression of pro-apoptotic factors in TECs. This study is one of only a few studies that have examined the local effect of IL-10 in TECs. IL-10 is a negative regulator of inflammation and apoptosis in the kidney. IL-10 may be relevant to the dysfunction after ischemia in humans.

Acknowledgements We thank M. Kawanishi, K. Furukawa, E. Honda, N. Mizuguchi, and S. Kurashimo for their expert technical assistance.

\section{Compliance with ethical standards}

Conflict of interest This study was funded by Takeda Medical Research Foundation and Japan Blood Products Organization.

\section{References}

1. Sheashaa H, Lotfy A, Elhusseini F, Aziz AA, Baiomy A, Awad S, et al. Protective effect of adipose-derived mesenchymal stem cells against acute kidney injury induced by ischemia-reperfusion in Sprague-Dawley rats. Exp Ther Med. 2016;11:1573-80.
B

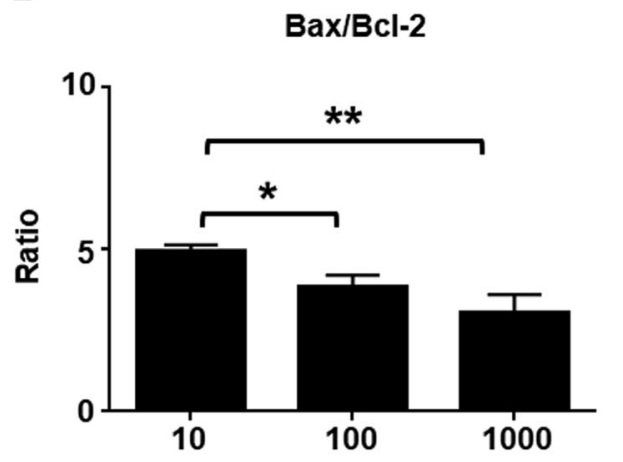

Recombinant IL-10 concentration ( $\mathrm{pg} / \mathrm{mL}$ )

treatments were compared by a one-way ANOVA followed by Dunnett's test for individual comparisons between group means. ${ }^{*} p<0.05$, $*^{*} p<0.01,10$ vs. $100 \mathrm{pg} / \mathrm{mL}$, and 10 vs. $1000 \mathrm{pg} / \mathrm{mL}$. The pictures show a representative band

2. Kelly KJ, Plotkin Z, Dagher PC. Guanosine supplementation reduces apoptosis and protects renal function in the setting of ischemic injury. J Clin Invest. 2001;108:1291-8.

3. Marko L, Vigolo E, Hinze C, Park JK, Roël G, Balogh A, et al. Tubular epithelial NF-kappaB activity regulates ischemic AKI. J Am Soc Nephrol. 2016;27:2658-69.

4. Zhao L, Xu L, Tao X, Han X, Yin L, Qi Y, et al. Protective effect of the total flavonoids from Rosa laevigata Michx fruit on renal ischemia-reperfusion injury through suppression of oxidative stress and inflammation. Molecules 2016; https://doi.org/10.3390/ molecules21070952.

5. Chen H, Wang L, Xing BZ, Liu XH, Chen ZY, Weng XD, et al. Ischemic postconditioning attenuates inflammation in rats following renal ischemia and reperfusion injury. Exp Ther Med. 2015;10:513-8.

6. Hu S, Zhang Y, Zhang M, Guo Y, Yang P, Zhang S, et al. Aloperine protects mice against ischemia reperfusion (IR)-induced renal injury by regulating PI3K/AKT/mTOR signaling and AP-1 activity. Mol Med. 2015;21:912-23.

7. Liu YE, Tong CC, Zhang YB, Jin HX, Gao Y, Hou MX, et al. Effect of dexmedetomidine on rats with renal ischemiareperfusion injury and the expression of tight junction protein in kidney. Int J Clin Exp Med. 2015;8:18751-7.

8. Pérez-de Puig I, Miró F, Salas-Perdomo A, Bonfill-Teixidor E, Ferrer-Ferrer M, Márquez-Kisinousky L, et al. IL-10 deficiency exacerbates the brain inflammatory response to permanent ischemia without preventing resolution of the lesion. J Cereb Blood Flow Metab. 2013;33:1955-66.

9. Miyauchi T, Uchida Y, Kadono K, Hirao H, Kawasoe J, Watanabe $\mathrm{T}$, et al. Preventive effect of antioxidative nutrient-rich enteral diet against liver ischemia and reperfusion injury. JPEN J Parenter Enteral Nutr. 2018;43:133-44.

10. Moore KW, de Waal Malefyt R, Coffman RL, O'Garra A. Interleukin-10 and the interleukin-10 receptor. Annu Rev Immunol. 2001;19:683-765.

11. de Waal Malefyt R, Abrams J, Bennett B, Figdor CG, de Vries JE. Interleukin 10 (IL-10) inhibits cytokine synthesis by human monocytes: an autoregulatory role of IL-10 produced by monocytes. J Exp Med. 1991;174:1209-20.

12. Fiorentino DF, Zlotnik A, Mossmann TR, Howard M, O'Garra A. IL-10 inhibits cytokine production by activated macrophages. J Immunol. 1991;147:3815-22. 
13. de Waal Malefyt R, Figdor CG, Huijbens R, Mohan-Peterson S, Bennett B, Culpepper, et al. Effects of IL-13 on phenotype, cytokine production, and cytotoxic function of human monocytes. Comparison with IL-4 and modulation by IFN-gamma or IL-10. J Immunol. 1993;151:6370-81.

14. D' Andrea A, Aste-Amezaga M, Valiante NM, Ma X, Kubin M, Trinchieri G. Interleukin 10 (IL-10) inhibits human lymphocyte interferon gamma-production by suppressing natural killer cell stimulatory factor/IL-12 synthesis in accessory cells. J Exp Med. 1993;178:1041-8.

15. Singh P, Castillo A, Majid DSA. Decrease in IL-10 and increase in TNF-a levels in renal tissues during systemic inhibition of nitric oxide in anesthetized mice. Physiol Rep. 2014;2:e00228.

16. Kitching AR, Katerelos M, Mudge SJ, Tipping PG, Power DA, Holdsworth SR. Interleukin-10 inhibits experimental mesangial proliferative glomerulonephritis. Clin Exp Immunol. 2002;128: 36-43.

17. Choi YK, Kim YJ, Park HS, Choi K, Paik S-G, Lee Y-I, et al. Suppression of glomerulosclerosis by adenovirus-mediated IL-10 expression in the kidney. Gene Ther. 2003;10:559-68.

18. Deng J, Kohda Y, Chiao H, Wang Y, Hu X, Hewitt SM, et al. Interleukin-10 inhibits ischemic and cisplatin-induced acute renal injury. Kidney Int. 2001;60:2118-28.

19. Semedo P, Correa-Costa M, Antonio Cenedeze M, Maria Avancini Costa Malheiros D, Antonia dos Reis M, Shimizu MH, et al. Mesenchymal stem cells attenuate renal fibrosis through immune modulation and remodeling properties in a rat remnant kidney model. Stem Cells. 2009;27:3063-73.

20. Donizetti-Oliveira C, Semedo P, Burgos-Silva M, Cenedeze MA, Malheiros DM, Reis MA, et al. Adipose tissue derived stem cell treatment prevents renal disease progression. Cell Transplant. 2012;21:1727-41.

21. Rodell CB, Rai R, Faubel S, Burdick JA, Soranno DE. Local immunotherapy via delivery of interleukin-10 and transforming growth factor $\beta$ antagonist for treatment of chronic kidney disease. J Control Release. 2015;206:131-9.

22. Arany I, Safirstein RL. Cisplatin nephrotoxicity. Semin Nephrol. 2003;23:460-4.

23. Nozaki Y, Kinoshita K, Yano T, Asato K, Shiga T, Hino S, et al. Signaling through the interleukin-18 receptor $\alpha$ attenuates inflammation in cisplatin-induced acute kidney injury. Kidney Int. 2012;82:892-902.

24. Nozaki Y, Nikolic-Paterson DJ, Yagita H, Akiba H, Holdsworth SR, Kitching AR. Tim-1 promotes cisplatin nephrotoxicity. Am J Physiol Renal Physiol. 2011;301:1098-104.

25. Nozaki Y, Nikolic-Paterson DJ, Snelgrove SL, Akiba H, Yagita $\mathrm{H}$, Holdsworth SR, et al. Endogenous Tim-1 (Kim-1) promotes Tcell responses and cell-mediated injury in experimental crescentic glomerulonephritis. Kidney Int. 2012;81:844-55.

26. Nozaki Y, Tamaki C, Yamagata T, Sugiyama M, Ikoma S, Kinoshita K, et al. All-trans-retinoic acid suppresses interferongamma and tumor necrosis factor-alpha; a possible therapeutic agent for rheumatoid arthritis. Rheumatol Int. 2006;26:810-7.

27. Wu H, Chen G, Wyburn KR, Yin J, Bertolino P, Eris JM, et al. TLR4 activation mediates kidney ischemia/reperfusion injury. J Clin Invest. 2007;117:2847-59.
28. Trinchieri G. Interleukin-10 production by effector $\mathrm{T}$ cells: Th1 cells show self control. J Exp Med. 2007;204:239-43.

29. Hunter CA, Ellis-Neyes LA, Slifer T, Kanaly S, Grünig G, Fort $\mathrm{M}$, et al. IL-10 is required to prevent immune hyperactivity during infection with Trypanosoma cruzi. J Immunol. 1997;158: 3311-6.

30. Gazzinelli RT, Wysocka M, Hieny S, Scharton-Kersten T, Cheever A, Kühn R, et al. In the absence of endogenous IL-10, mice acutely infected with Toxoplasma gondii succumb to a lethal immune response dependent on CD4t T cells and accompanied by overproduction of IL-12, IFN-gamma and TNF-alpha. J Immunol. 1996;157:798-805.

31. Latifi SQ, O'Riordan MA, Levine AD. Interleukin-10 controls the onset of irreversible septic shock. Infect Immun. 2002;70: 4441-6.

32. Sewnath ME, Olszyna DP, Birjmohun R, ten Kate FJ, Gouma DJ, van Der Poll T. IL-10-deficient mice demonstrate multiple organ failure and increased mortality during Escherichia coli peritonitis despite an accelerated bacterial clearance. J Immunol. 2001;166: 6323-31.

33. Gloor B, Todd KE, Lane JS, Rigberg DA, Reber HA. Mechanism of increased lung injury after acute pancreatitis in IL-10 knockout mice. J Surg Res. 1998;80:110-4.

34. Schneider CP, Schwacha MG, Chaudry IH. The role of interleukin-10 in the regulation of the systemic inflammatory response following trauma hemorrhage. Biochim Biophys Acta. 2004;1689:22-32.

35. Diefenhardt P, Nosko A, Kluger MA, Richter JV, Wegscheid C, Kobayashi Y, et al. IL-10 receptor signaling empowers regulatory $\mathrm{T}$ cells to control Th17 responses and protect from GN. J Am Soc Nephrol. 2018;29:1825-37.

36. Abe H, Yamanishi T, Mashidori T, Arai K, Kamai T. Significant association of interleukin 10 receptor mRNA levels with renal cell carcinoma metastasis. Biomed Res. 2008;29:19-25.

37. Ito S, Ansari P, Sakatsume M, Dickensheets H, Vazquez N, Donnelly RP, et al. Interleukin-10 inhibits expression of both interferon alpha- and interferon gamma-induced genes by suppressing tyrosine phosphorylation of STAT1. Blood. 1999;93:1456-63.

38. Donnelly RP, Dickensheets H, Finbloom DS. The interleukin-10 signal transduction pathway and regulation of gene expression in mononuclear phagocytes. $\mathrm{J}$ Interferon Cytokine Res. 1999;19:563-73.

39. Wan X, Huang WJ, Chen W, Xie HG, Wei P, Chen X, et al. IL-10 deficiency increases renal ischemia-reperfusion injury. Nephron Exp Nephrol. 2014;128:37-45.

40. Andres-Hernando A, Okamura K, Bhargava R, Kiekhaefer CM, Soranno D, Kirkbride-Romeo LA, et al. Circulating IL-6 upregulates IL-10 production in splenic CD4+ T cells and limits acute kidney injury-induced lung inflammation. Kidney Int. 2017;91:1057-69.

41. Kuhn KA, Manieri NA, Liu TC, Stappenbeck TS. IL-6 stimulates intestinal epithelial proliferation and repair after injury. PLoS ONE. 2014;9:e114195. https://doi.org/10.1371/journal.pone. 0114195 